than the higher, or else two distinct series; and he inclines to the latter view. Both, however, must be separated from the Laurentian by a great interval of time, and neither exhibits metamorphism comparable with that of a series of schists and gneisses, like the so-called Montalban. The newer reminds him often of the English Pebidians.

\title{
CORIESPONDENOE.
}

LYDEKKER, BOULENGER, AND DOLLO ON FOSSIL TORTOISES.

SIR,- I have read with interest the notes on the above subject which appeared in the Grological Magazin e for June and September, I find that the two first-named gentlemen have overlooked a paper of mine, which will relieve me of the charge of erroneous treatment of the genus Pleurosternum which they make. The paper was published in $1870,{ }^{1}$ and prior to those of Professor Rütimeyer which they cite as authority for determination already made by me. The learned authors quote me as stating that in the genus Pleurosternum there is "no intergular shield, and the genus is accordingly referred by me to the Cryptodira; whereas its true position, as was pointed out by Prof. Riitimeyer, is with the Pleurodira; and with that group-the Pelomedusidæ and Peltocephalidæ of Gray-characterized by the presence of eleven, instead of nine, plastral bones." On a subsequent page (274-5) they consider the Platemys Bowerbankii, of Owen and Bell, " in regard to which Prof. Rütimeyer has already pointed out that the specimen figured by the same writers under the name of Emys lavis is merely the young of the former, and that owing to the presence of a small mesoplastral bone, the reference to Platemys is incorrect, and it is suggested that the species may probably belong either to Podocnemis or Peltocephalus." "

In my paper of 1870 I remark, "The genus Platemys as adopted [in Maack's work] may be cited. It embraces nine species according to the present work, the genus Pleurosternum of Owen being referred to it. This is done because the additional pair of thoracic bones which characterizes it is found in a rudimental condition in Platemys Bowerbankii; and Platemys Bullockii of Owen presents the intermarginal scuta of Pleurosternum, and because of the general resemblance in specific characters between the latter and the $P l$. concinnum. To us, however, the genus Pleurostemum appears to be Cryptodire, not Pleurodire, as it lacks the intergular scutum of the later suborder, and to represent a peculiar family of that group characterized by the possession of ten instead of eight sternal bones. Platemys Bullockii, P. Bowerbankii, and Emys lavis, Owen and Bell, appear on the other hand to be Pleurodira, and to be referable to two families of that suborder. The Pl. Bullockii, on account of its five pairs of sternal bones, to the Sternothæridæ, and on account of

1 Die bis jetzt bekannten Schildkörten, u. d. bei Theilheim in IIannover neu afgefunden altesten Arten derselben; von Dr. G. A. Maack; a review by E. D. Cope, Amer. Journal Sei. Arts, 1870, L. pp. 136.

2 "The figure shows that its affinity appears to be rather with the former than the latter, and it may accordingly be provisionally referred to that genus." 
its intermarginal scuta to a new genus, which I call Digerrhum. The last two in their rudimental fifth pair of sternals, resemble many Pleurodira, and cannot be distinguished from the genus Podocnemis now living in the Amazon."

In this paragraph I have made the references adopted by Rütimeyer, Lydekker and Boulenger, but I did not use the name Pleurosternum for the Pl. Bulloclii. Believing that the Pl. concinnum represented that genus, I removed the $P l$. Bullockii from it. It now remains to ascertain the characters of the Pleurosternum concinnum, since no reference is made to it by the authors of the paper on which I am now commenting, but who regard the $\mathrm{Pl}$. Bullockii as typical of the genus.

M. Dollo well remarks (September Number) that the absence of dermal sutures cannot alone place a genus of Tortoises in a separate. family from forms which possess such sutures. He regards Erquilenesia as most resembling Euclastes, but not to belong to the Propleuridæ. But I think Euclastes is one of that group, and I suspect that Dollo's characters of the skull define the group better than the number of costal bones, which will however distinguish the genera.

E. D. Cope.

\section{ORIGIN OF CERTAIN BANDED GNEISSES.}

Srk,-Mr. Teall's paper on the origin of certain banded gneisses (p. 484) is a contribution of the utmost value to the discussion of a very difficult subject. But, as I am responsible for another theory concerning these gneisses, may I be allowed to say, that though I admit the importance of the hypothesis, I still see great difficulties in the way of accepting it. These gneisses of the Lizard must not be regarded alone; a hypothesis which might alleviate our difficulties here (and they are undoubtedly great) might increase them elsewhere-and thus, did I assign an igneous origin to all the crystalline rocks south of St. Keverne, I should find it difficult to know where to stop in applying the explanation to other resions. Moreover, if we are to explain these banded gneisses as the rolling or crushing out of a complex of igneous rocks, not only must the flexibility of the rocks have been very great, but also this complex originally must have been a very intricate one. Now I have had a fairly large experience in the habits of igneous rocks, and, so far as this goes, such complications as would be requirer here are both rare in occurrence and limited in extent. Yet at the Lizard the banded series is of considerable thickness, and can be traced along the coast for full two miles. I admit, however, that when I wrote my two papers, I sometimes failed to distinguish between structures significant of original constitution and those due to subsequent mechanical action, for our knowledge of the latter is of very recent date; but to what extent I will not venture to say until I can again examine the whole district. This I hope to do, but for various reasons must defer the pleasure for a time. Probably it will be some years before we can fairly determine the claims of conflicting hypotheses ; meanwhile it is well for science that $\mathrm{Mr}$. Teall has advanced one with so much moderation in statement, and clearness in reasoning. Perhaps 